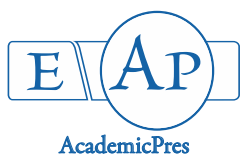

Ouled Taarabat K et al. (2021)

Notulae Scientia Biologicae

Volume 13, Issue 3, Article number 10975

DOI: $10.15835 / \mathrm{nsb} 13310975$

Research Article

\title{
Antimicrobial activity and chemical constitution of essential oil from Moroccan thyme (Thymus satureioides C.) on five microbial contaminants
}

\author{
Kamal OULED TAARABT ${ }^{1}$, Rachida OUAABOU², \\ Rachid LAHLALI ${ }^{3}$, Said ENNAHLI ${ }^{3 *}$ \\ ${ }^{1}$ Chouaib Doukkali University, Faculty of Sciences of El Jadida, Department of Biology, Morocco; Taarabtkamal@gmail.com \\ ${ }^{2}$ Cadi Ayyad University, Faculty of Science Semlalia, Department of Chemistry, Marrakesh, Morocco; rachaouaabou@gmail.com \\ ${ }^{3}$ National School of Agriculture, Meknes, Morocco; lahlalir@gmail.com; ennahlisaid@gmail.com (*corresponding author)
}

\begin{abstract}
Antimicrobial preservatives are widely added to health products to prevent microbial contamination. However, because of the risks attributed to several synthetic agents, manufacturers are searching for new natural agents. Therefore, this work investigated the different physicochemical characteristics of one of those natural ingredients, the essential oil (EO) of Moroccan thyme (Thymus satureioides $\mathrm{C}$.) and its antimicrobial potential against five microbial strains. The physicochemical parameters (density, refractive index, optical rotation, miscibility, acid value, ester value, and flash point) were measured and the chemical composition was determined by GC/MS. The antimicrobial activity was assessed using disc diffusion method and a macrodilution broth method. The EO yield was $1.01 \%$ compared to the dry matter. Fifty-two compounds were identified. The major compounds were thymol (28.66\%), borneol (21.16\%) and $\alpha$-terpineol (12.33\%). The disc diffusion method revealed that all the strains tested showed sensitivity to the EO at concentration of 1636 $\mu \mathrm{g}$ per disc. For the minimum inhibitory concentration (MIC) and the minimum microbicidal concentrations (MMC), similar results were obtained for Staphylococcus aureus and Escherichia coli $(640 \mu \mathrm{g} / \mathrm{mL})$, for Pseudomonas aeruginosa $(960 \mu \mathrm{g} / \mathrm{mL})$ and for Candida albicans $(800 \mu \mathrm{g} / \mathrm{mL})$ baring Aspergillus brasiliensis, which had $480 \mu \mathrm{g} / \mathrm{mL}$ and $640 \mu \mathrm{g} / \mathrm{mL}$ for the MIC and MMC, respectively.
\end{abstract}

Keywords: antibacterial; chemical composition; essential oil; MIC; MMC; thyme (Thymus satureioides $\mathrm{C}$.)

\section{Introduction}

Antimicrobial preservatives are widely used in various health products and are cheap and effective ingredients against a wide range of spoilage organisms. When a health product does not itself have adequate antimicrobial activity, antimicrobial preservatives may be added, to protect it from microbiological growth or from microorganisms that are introduced inadvertently during or subsequently in the manufacturing process (Meyer et al., 2007; Khorshidian et al., 2018).

Received: 11 May 2021. Received in revised form: 21 Jul 2021. Accepted: 11 Aug 2021. Published online: 18 Aug 2021. From Volume 13, Issue 1, 2021, Notulae Scientia Biologicae journal uses article numbers in place of the traditional method of continuous pagination through the volume. The journal will continue to appear quarterly, as before, with four annual numbers. 
All antimicrobial preservatives used must be proven to be nontoxic for human. The safety and efficiency of preservatives are the fundamental factors to be considered for long-term preservation of health products. However, some synthetic preservatives are not inconsequential, primarily due to their excessive use not only in health products, but also in food and household products. Due to increased public concerns the demand for natural or label-friendly alternatives has drastically increased (Falleh et al., 2020).

Chemical components of plant extracts have the potential to provide a green alternative to conventional chemical antimicrobial preservatives. Recently, there is more focus on replacing chemical preservatives, which might have adverse effects on human health and environment with those of plant-based natural ones (Munda et al., 2019; Lal et al., 2019, 2020). Increasing demand for natural health product preservatives has resulted in

essential oils (EOs) becoming more popular. The EOs are gaining much recognition as a potential source of natural bioactives. As part of this study, an attempt was made to develop effective and safe preservatives from natural products by selecting thyme from the Lamiaceae family as a representative of Moroccan medicinal plants and aromatics. Generally, thyme species were considered to be medicinal plants because of their pharmacological and biological properties (Al-Maqtari et al., 2011).

Among these endemic species, Thymus satureioides C. (T. satureioides C.) was known locally in Morocco as "Azukni" or "Zaiitra", and worldwide as "Moroccan thyme". This species is widespread in the Mediterranean basin of North Africa (Sakkas and Papadopoulou, 2017), typical of arid habitats (Ismaili et al., 2004). In Morocco, T. satureioides C. grows spontaneously in the low and middle mountains of the High Atlas and Anti-Atlas (Laila et al., 2014). T. satureioides Coss. is a perennial shrub, about half a meter in height with spatulate leaves and purple corolla. It is locally used as a food spice, and essential pain-killer in folk medicine for healing gastrointestinal disorders, antisepsis (Bellakhdar et al., 1991; Fatima-Zahra et al., 2017), diabetes (Tahraoui et al., 2007), respiratory disorders (Rebbas and Bounar, 2014), and to warm the body (Elkhoudri et al., 2016).

Recent studies have shown that Thymus species have high antioxidant, anti-haemolytic (Ramchoun et al., 2015), hypolipidaemic (Ramchoun et al., 2012), anti-inflammatory (Khouya et al., 2019), anticancer and bio-insecticidal potential (Alaoui-Jamali et al., 2018). Furthermore, several reports highlighted the antimicrobial activity of EO of Moroccan thyme (El Bouzidi et al., 2013; Boubaker et al., 2016; Chraibi et al., 2016). In order to emphasize the benefits of Moroccan thyme, this study aimed at determining the physicochemical parameters and chemical composition of $\mathrm{EO}$ extracted from $T$. satureioides $\mathrm{C}$., as well as the in vitro study of its antimicrobial activity against the microbes involved in the deterioration of health products.

\section{Materials and Methods}

\section{Plant material}

The leafy stems of T. satureioides $\mathrm{C}$ amounting to $5 \mathrm{~kg}$ were collected in 2018 from Al Haouz province, in the Tidili Mesfioua district ( $31^{\circ} 26^{\prime} 37.3^{\prime \prime} \mathrm{N}, 07^{\circ} 36^{\prime} 26.5^{\prime \prime} \mathrm{W}$, altitude $\left.1119 \mathrm{~m}\right)$, Morocco, during flowering period. Samples were dried at $105^{\circ} \mathrm{C}$ until constant weight and cut into small pieces. The dried thyme was kept in a stainless-steel container for later analysis.

\section{Essential oil isolation}

Thyme essential oil was isolated by hydro distillation of the plant material. Briefly, about $500 \mathrm{~g}$ of fresh botanical material were transferred to Clevenger apparatus and $3 \mathrm{~L}$ of distilled water was added. The Clevenger apparatus was set at boiling temperature of water for $3 \mathrm{~h}$ and thyme essential oil was distilled. The EO was spontaneously separated from the water solution and collected in a $50 \mathrm{~mL}$ flacon tube containing $0.5 \mathrm{~g}$ anhydrous sodium sulfate. The extract was vortexed for $30 \mathrm{~s}$ and centrifuged at $2000 \mathrm{~g}$ for $10 \mathrm{~min}$ at $5^{\circ} \mathrm{C}$. The EO sample was conditioned in a sealed tinted vial and stored in a refrigerator at $4{ }^{\circ} \mathrm{C}$. 


\section{Physicochemical parameters}

The average yield was calculated from the weight of the EO obtained at the end of isolation using the equation below:

Percentage yield $=[$ weight of the extracted oil $(\mathrm{g}) /$ dry weight of the sample $(\mathrm{g})] \times 100$

The appearance, colour, smell, consistency and solubility of the EO were recorded. The standards used to determine physicochemical parameters were NF ISO 280 for the refractive index, NF ISO 592 for the optical rotation, NF EN ISO 660 for the acid value, NF ISO 709 for the ester value, NF ISO 1241 for the ester value after acetylation, the AFNOR standard for ethanol miscibility, the "Closed Cup" method for flash point measurement and the electronic density meter for relative density.

Gas chromatography analyses (GC/MS)

Gas Chromatography-Mass Spectrometry analysis was carried out using an HP 6890 apparatus and a 20 $\mathrm{m} \times 0.18 \mathrm{~mm}$ DB-5ms (cross-linked 5\% phenyl/95\% dimethyl arylenepolysiloxane) column with $0.18 \mu \mathrm{m}$ film thickness (Agilent). Carrier gas was helium, the flow rate was $3 \mathrm{~mL} / \mathrm{min}$. Column temperature was initially kept at $50^{\circ} \mathrm{C}$ for $3 \mathrm{~min}$, then gradually increased to $320^{\circ} \mathrm{C}$ at a rate of $10^{\circ} \mathrm{C} / \mathrm{min}$. Oil samples $(2 \mu \mathrm{L}$, neat $)$ were injected using the split mode (1:50 ratio). Mass spectra were taken over the $\mathrm{m} / \mathrm{z}$ 30-500 range with an ionizing voltage of $70 \mathrm{eV}$. Kovat's retention index was calculated using cochromatographed standard hydrocarbons. The individual compounds were identified by MS and their identity was confirmed by comparison of their RIs, relative to C8-C32 n-alkanes, and mass spectra with those of authentic samples or with data already available in the NIST 2007 Mass Spectral Library and the literature (Adams, 2005).

Samples were analysed in triplicate.

\section{Antimicrobial activity}

Microbial strains

Reference strains, representing likely contaminants to health products, were obtained from the American Type Culture Collection (ATCC) according to the recommendations of the challenge test of the European Pharmacopoeia. Three bacterial strains: Pseudomonas aeruginosa (ATCC 9027), Staphylococcus aureus (ATCC6538) and Escherichia coli (ATCC 8739), and two fungal strains: Candida albicans (ATCC 10231), and Aspergillus brasiliensis (ATCC 16404) were used in this study.

\section{Disc diffusion method}

The antimicrobial activity of the EO was determined by disc diffusion method EUCAST (EUCAST, 2019) with some modifications. In a nutshell, a suspension containing $1 \times 10^{8}$ to $2 \times 10^{8}$ colony-forming units $(\mathrm{CFU}) / \mathrm{mL}$ of bacteria cells and 1 to $2.5 \times 10^{5}$ spores $/ \mathrm{mL}$ of fungi were inoculated on Petri dishes containing $4 \mathrm{~mm}$ thick Mueller-Hinton agar (MHA) and Potato dextrose agar (PDA) medium, respectively. The $6 \mathrm{~mm}$ filter paper discs were impregnated with $15 \mu \mathrm{l}$ of stock solutions $(1636 \mu \mathrm{g})$ of EO determined by weighing. The discs were aseptically placed on the surface of the growth-medium with sterile forceps and gently pressed to ensure contact with agar, which had previously been inoculated with the selected test microorganism. Positive control consisted of $0.2 \%$ chlorhexidine digluconate solution (20\%), a synthetic preservative. Discs without EOserved as a negative control. The 15-15-15-minute rule was respected. Inoculum suspension was prepared within 15 minutes, discs were applied within 15 minutes of inoculation and plates were incubated within 15 minutes of discs application. The plates were incubated at $35^{\circ} \mathrm{C}$ for $16-24 \mathrm{~h}$ for bacteria, $24 \mathrm{~h}$ for C. albicans at $35^{\circ} \mathrm{C}$ and $24-48 \mathrm{~h}$ for $A$. brasiliensis at $25^{\circ} \mathrm{C}$. EO activity was assessed by measuring the inhibition zone diameters, including the diameter of discs.

\section{Determination of the minimum inhibitory concentration (MIC)}

The MIC was defined as the lowest concentration of an antimicrobial agent that prevents visible growth of a micro-organism. A macro-dilution broth was used to measure quantitatively the in vitro activity of the EO 
against the studied micro-organism, as reported in CLSI standards (formerly the NCCLS) with some modifications. The methods M07-A9(CLSI., 2012), M27-A2(NCCLS., 2002a), M38-A (NCCLS., 2002b) were used for bacteria, yeasts and filamentous fungi, respectively. Briefly, a series of 10 tubes was prepared with a broth (Mueller-Hinton for bacteria and RPMI-1640 for fungi) with various concentrations of the EO ranging from 160 to $1600 \mu \mathrm{g} / \mathrm{mL}$ (Table 1). The dimethyl sulfoxide (DMSO) was used to solubilize the EO. The final concentration of DMSO was reduced to $1 \%$.

The tubes were inoculated with a standardised suspension of the test organisms. Tested strains were prepared by adjusting the turbidity of each microbial culture to reach an optical density of $0.5 \mathrm{McFarland}$ standards. These resulted in a suspension containing approximately 1 to $2 \times 10^{8} \mathrm{CFU} / \mathrm{mL}$ for bacteria, 1 to 5 $\times 10^{6} \mathrm{CFU} / \mathrm{mL}$ for yeast $C$. albicans and $10^{6}$ spores $/ \mathrm{mL}$ for $A$. brasiliensis. After incubation for $16-20 \mathrm{~h}$ at 35 ${ }^{\circ} \mathrm{C}$ for bacteria and $46-50 \mathrm{~h}$ for fungal strains at $25^{\circ} \mathrm{C}$, the tests were examined and the MIC was determined. The controls of growth, solvent and sterility were prepared. The determinations of MIC values were done in triplicate.

Table 1. Diagram of preparation of the dilution range of the EO used in macro-dilution

\begin{tabular}{|c|c|c|c|c|c|}
\hline \multirow{2}{*}{ Tube $\mathrm{N}^{\circ}$} & \multirow{2}{*}{$\begin{array}{l}\text { VEO } \\
(\mu \mathrm{L})\end{array}$} & \multirow{2}{*}{$\begin{array}{c}\text { VDMSO } \\
(\mu \mathrm{L})\end{array}$} & \multirow{2}{*}{$\begin{array}{c}{[\mathrm{EO}]_{\text {Initial }}} \\
(\%, \mathrm{v} / \mathrm{v})\end{array}$} & \multicolumn{2}{|c|}{$[\mathrm{EO}]_{\mathrm{Final}}$} \\
\hline & & & & $(\%, \mathrm{v} / \mathrm{v})$ & $(\mu \mathrm{g} / \mathrm{mL})$ \\
\hline 1 & 450 & 2550 & 15 & 0.15 & 1600 \\
\hline 2 & 405 & 2595 & 13.5 & 0.135 & 1440 \\
\hline 3 & 360 & 2640 & 12 & 0.12 & 1280 \\
\hline 4 & 315 & 2685 & 10.5 & 0.105 & 1120 \\
\hline 5 & 270 & 2730 & 9 & 0.09 & 960 \\
\hline 6 & 225 & 2775 & 7.5 & 0.075 & 800 \\
\hline 7 & 180 & 2820 & 6 & 0.06 & 640 \\
\hline 8 & 135 & 2865 & 4.5 & 0.045 & 480 \\
\hline 9 & 90 & 2910 & 3 & 0.03 & 320 \\
\hline 10 & 45 & 2955 & 1.5 & 0.015 & 160 \\
\hline
\end{tabular}

VEO: Volume of EO contained in the stock solution.

VDMSO: Volume of the solvent contained in the stock solution.

$[\mathrm{EO}]_{\text {Initial }}$ : EO concentration when initially mixing with the solvent for the preparation of the stock solution.

$[\mathrm{EO}]_{\text {Final }}$ : EO concentration in the incubation tube expressed in $(\%, \mathrm{v} / \mathrm{v})$ and converted to $(\mu \mathrm{g} / \mathrm{mL})$ because the density of the EO is known $(\mathrm{d}=0.9379)$.

\section{Determination of the minimum microbicidal concentration (MMC)}

The MMC is the lowest concentration of EO capable of reducing microorganisms to zero. The MMC is measured by subculturing the broths used to determine MIC onto fresh agar plates. An aliquot was taken with a calibrated loop on the tubes used in MIC assay from the last tube provided with microbial growth and spread on MHA for $24 \mathrm{~h}$ at $35^{\circ} \mathrm{C}$ for bacteria, and on Sabouraud agar for $24-72 \mathrm{~h}$ at $25^{\circ} \mathrm{C}$ for fungi. The $\mathrm{MMC}$ of $\mathrm{EO}$ was determined from the first microbial-free box. The $\mathrm{EO}$ of thyme was considered as microbicide if the MMC/MIC ratio=1, or as bacteriostatic or fungistatic if the MMC/MIC ratio $\geq 2$ (Konaté et al., 2012). The determinations of MMC values were performed in triplicate.

\section{Statistical analysis}

The EO samples were analysed in triplicate and the data are reported as mean \pm SD. Statistical analysis was carried out by a Fisher's test using the SPSS statistical software v 22. Values of $P<0.05$ were considered statistically significant. 


\section{Results and Discussion}

\section{Physicochemical parameters}

Hydro distillation of the dried leaf stems of T. satureioides C. yielded yellow liquid oil, mobile, and immiscible with water. The oil had an aromatic herbaceous smell characteristic of the plant. The essential oil yield was $1.01 \% \pm 0.14$ on dry weight basis. The physicochemical parameters are shown in Table 2 .

Organoleptic characteristics were identical to a study reported on the T. satureioides Moroccan thyme (Kasrati et al., 2014). According to previous studies carried out on the same plant in Morocco, the yield ranged from $0.2 \%$ to 3.3\% (Taoufik et al., 2017). Ramzi et al. (2017) attributed these differences in yield to the plant phenological stages. In regards to physicochemical parameters of the EO of thyme, to the best of our knowledge, no research has been conducted. The majority of studies were focused exclusively on the chemical composition of Moroccan thyme.

Table 2. Physicochemical parameters of the EO of T. satureioides $\mathrm{C}$. leafy stems

\begin{tabular}{|l|c|}
\hline Parameter & Value \\
\hline Relative density at $20{ }^{\circ} \mathrm{C}$ & 0.9379 \\
\hline Refractive index at $20^{\circ} \mathrm{C}$ & 1.4928 \\
\hline Optical rotation at $20^{\circ} \mathrm{C}$ & +3.38 \\
\hline Miscibility with ethanol $80 \% \mathrm{~V} / \mathrm{V}$ at $20^{\circ} \mathrm{C}$ & $>10$ \\
\hline Acid value in $\mathrm{mg} \mathrm{KOH} / \mathrm{gr}$ & 8.9 \\
\hline Acid value in $\%$ of oleic acid & 4.5 \\
\hline Ester value & 18 \\
\hline Ester value after acetylation & 234 \\
\hline Flash point (closed cup method) in ${ }^{\circ} \mathrm{C}$ at $101.3 \mathrm{kPa}$ & 14 \\
\hline
\end{tabular}

Tests were performed in triplicate and modal values are presented.

\section{Chemical composition of the essential oil}

The identified principal components of the T. satureioides C. essential oil is listed in Table 3. The GC/MS analyses of the essential oil, lead to the identification of fifty-two compounds representing $96.38 \%$ of the total oil composition.

Major compounds of the T. satureioides C. were thymol (28.66\%) followed by borneol (21.16\%), $\alpha$ terpineol (12.33\%), $\beta$-caryophyllene (6.39\%) and carvone (5.49\%), while other compounds were present under $2 \%$. The EO of T. satureioides $\mathrm{C}$. displayed a high content of monoterpenes $(85.05 \%)$ and low contents of sesquiterpenes (11.33\%). The major constituents of oxygenated monoterpenes were alcohols $(37.55 \%)$ followed by phenols $(30.62 \%)$ and ketones (5.91\%). A small number of esters (0.96\%) and ether-oxides $(0.656 \%)$ were detected.

The total of chemical compounds ( 52 compounds) reported in this study were close to those reported by Taoufik et al. (2017) who reported 56 compounds. However, other authors reported a lower number $(20$ compounds) (Chraibi et al., 2016).

The quantitative and qualitative chemical composition showed a significant variability. It is impossible to find a chemically homogeneous and standardised EO for thymus species in its natural habitat (Aicha et al., 2013), nonetheless, the presence of common compounds such as carvacrol, borneol, and thymol, which are ubiquitous major components in varying amounts, cannot be ruled out (Jaafari et al., 2007; Lahnine et al., 2017; Rahman, 2018). Also, the current study found that, borneol is the only compound with a percentage that consistently exceeds 20\%, while it reported at lower percentage (around 10\%) in Thymus capitatus and Thymus bleicherianus (Ainane et al., 2019). Therefore, it can be concluded that T. satureioides $\mathrm{C}$ has a borneol chemotype. 
Table 3. Chemical composition of the essential oil of T. satureioides C. leafy stems by GC/MS

\begin{tabular}{|c|c|c|c|c|c|c|c|}
\hline Compounds & RT & $\mathrm{RT}^{*}$ & $\begin{array}{c}\text { Conc. } \\
\%\end{array}$ & Compounds & RT & $\mathrm{RT}^{*}$ & $\begin{array}{c}\text { Conc. } \\
\%\end{array}$ \\
\hline Tricyclene & 4.96 & 5.53 & 0.064 & $\alpha$-Terpineol & 9.94 & 15.21 & 12.33 \\
\hline$\alpha$-Thujene & 5.06 & 5.62 & 0.109 & Cis-Dihydro carvone & 9.96 & 15.41 & 0.24 \\
\hline$\alpha$-Pinene & 5.2 & 5.85 & 0.911 & Verbenone & 10.12 & 15.97 & 0.041 \\
\hline Camphene & 5.54 & 6.26 & 1.825 & Nerol & 10.34 & 16.97 & 0.023 \\
\hline Sabinene & 6.01 & 6.91 & 0.068 & BornyleFormate & 10.4 & 17.36 & 0.359 \\
\hline$\beta$-Pinene & 6.1 & 7.04 & 0.252 & Carvone & 10.54 & 17.53 & 5.498 \\
\hline Octene-3-ol & 6.19 & 7.04 & 0.018 & Linalyl Acetate & 10.62 & -- & 0.082 \\
\hline Myrcene & 6.36 & 7.43 & 0.337 & Isothymol & 11.15 & 20.14 & 0.109 \\
\hline 3-Octanol & 6.52 & 7.44 & 0.09 & Bornyl Acetate & 11.2 & 19.62 & 0.247 \\
\hline$\alpha$-phellandrene & 6.66 & 7.85 & 0.038 & Thymol & 11.32 & 19.71 & 28.66 \\
\hline$\delta$-3-carene & 6.7 & 8.10 & 0.023 & Carvacrol & 11.41 & 20.14 & 1.854 \\
\hline$\alpha$-Terpinene & 6.87 & 8.30 & 0.333 & $\alpha$-Terpinyl Acetate & 12.06 & -- & 0.276 \\
\hline$p$-Cymene & 7.02 & 8.53 & 2.768 & $\alpha$-Copaene & 12.45 & 23.49 & 0.071 \\
\hline Limonene & 7.1 & 8.69 & 0.403 & $\beta$-Bourbonene & 12.57 & 24.05 & 0.035 \\
\hline$\beta$-phellandrenne & 7.12 & 8.70 & 0.077 & $\beta$-Caryophyllene & 13.05 & 25.36 & 6.395 \\
\hline Eucalyptol & 7.16 & 8.76 & 0.656 & Aromadendrene & 13.25 & 26.27 & 2.234 \\
\hline (E)- $\beta$-Ocimene & 7.42 & 9.42 & 0.011 & $\alpha$-Humulene & 13.49 & 26.82 & 0.317 \\
\hline$\gamma$-Terpinene & 7.63 & 7.78 & 1.879 & Allo-Aromadendrene & 13.54 & 27.07 & 0.019 \\
\hline Cis- Sabinene hydrate & 7.85 & 10.2 & 0.048 & Germacrene-D & 13.81 & 28.15 & 0.012 \\
\hline Terpinolene & 8.1 & 10.98 & 0.165 & $\gamma$-cadinene & 14.2 & 29.35 & 0.142 \\
\hline$p$-Cymenene & 8.19 & 11.09 & 0.036 & $\delta$-cadinene & 14.25 & 29.72 & 0.106 \\
\hline Linalol & 8.37 & 11.32 & 2.467 & Spathulenol & 14.96 & 31.96 & 0.039 \\
\hline Cis-Thujone & 8.45 & 11.56 & 0.007 & Caryophyllene Oxide & 15.04 & 32.16 & 1.179 \\
\hline Trans-Thujone & 8.69 & 12.00 & 0.008 & $\begin{array}{c}\text { Caryophylla- } \\
4(12), 8(13) \text {-diene } 5-\beta- \\
\text { ol }\end{array}$ & 15.67 & 34.40 & 0.351 \\
\hline Camphre & 9.15 & -- & 0.117 & & & & \\
\hline Borneol & 9.59 & 14.29 & 21.158 & Epi- $\beta$-Cadinol & 15.71 & 34.38 & 0.429 \\
\hline Terpinene-4-ol & 9.68 & 16.66 & 1.46 & Total (\%) & & & 96.376 \\
\hline
\end{tabular}

RT: Retention time

RT*: Retention time from literature (Adams, 2017, NIST Chemistry Web Book, SRD 69).

Antimicrobial activity of the EO of Thymus satureioides $C$.

Disc diffusion is one of the most largely used antimicrobial susceptibility tests. It is suitable for the majority of micro-organisms in the range of antimicrobial agents that can be tested and requires no special equipment.

The antimicrobial activity of $T$. satureioides $\mathrm{C}$. EO by disc diffusion method against five microbial strains, are shown in Table 4 . At dose of $1639 \mu \mathrm{g} / \mathrm{disc}$ the EO of thyme shows antimicrobial activity against the five tested strains.

The data indicated that maximum activity was observed against $A$. brasiliensis $(32.00 \mathrm{~mm})$, followed by C. albicans and E. coli $(13.00 \mathrm{~mm})$. Moderate activity was observed against $S$. aureus, with inhibition zone of $(8.50 \mathrm{~mm})$. P. aeruginosa was considered as resilient since a small inhibition zone $(7.50 \mathrm{~mm})$ was observed.

The MIC and MMC results are summarized in Table 5. $P$. aeruginosa remained the most resilient strain to the EO of thyme compared to other strains. The growth of $P$. aeruginosa was inhibited at $960 \mu \mathrm{g} / \mathrm{mL}$, while A. brasiliensis was inhibited at $480 \mu \mathrm{g} / \mathrm{mL}$. The EO had a bacteriostatic action at a concentration of $640 \mu \mathrm{g} / \mathrm{mL}$ for $S$. aureus and $E$. coli and a fungistatic action at a concentration of $800 \mu \mathrm{g} / \mathrm{mL}$ for $C$. albicans. MMC showed that all micro biostatic concentrations were microbiocidal, except for $A$. brasiliensis. The fungicidal action 
requires a higher concentration $(640 \mu \mathrm{g} / \mathrm{mL})$, which is normal since the fungus developed a form of resistance to adverse conditions.

The intraspecific chemical variability of the $\mathrm{EO}$ of the T. satureioides $\mathrm{C}$. was no longer surprising and can be attributed to a set of factors, including genetic factors, environmental conditions ( soil, precipitation, temperature, light, stress, etc.), geographical origin, vegetative cycle, biotic effects (the harvest period and the methods used for conservation and isolation) (Jaafari et al., 2007; Aicha et al., 2013; Kasrati et al., 2014).

Table 4. Antimicrobial activity of $T$. satureioides $\mathrm{C}$. EO by disc diffusion method against five microbial strains

\begin{tabular}{|c|c|c|c|c|c|}
\hline & S. aureus & E. coli & P. aeruginosa & C. albicans & A. brasiliensis \\
\hline $\boldsymbol{\emptyset}_{\mathbf{m}}$ & $8.5 \pm 0.1^{\mathrm{c}}$ & $13 \pm 0.0^{\mathrm{b}}$ & $7.5 \pm 0.1^{\mathrm{cd}}$ & $13 \pm 0.2^{\mathrm{b}}$ & $32 \pm 0.4^{\mathrm{a}}$ \\
\hline
\end{tabular}

$\emptyset_{\mathrm{m}}$ : mean diameter of the halo of inhibition of the $\mathrm{EO}$ of the Thymus satureioides $\mathrm{C}$. measured in $\mathrm{mm}$.

Means followed by the same letter in the same row are not significantly different $(\mathrm{P}<0.05)$.

Table 5. Minimum inhibitory and minimum microbicidal concentration of T. satureioides $\mathrm{EO}$ against five microbial strains

\begin{tabular}{|c|c|c|c|c|c|c|c|c|c|c|}
\hline \multirow{2}{*}{$\begin{array}{l}{[\mathrm{EO}]_{\text {Final }}} \\
(\mu \mathrm{g} / \mathrm{mL})\end{array}$} & \multicolumn{2}{|c|}{ S.aureus } & \multicolumn{2}{|c|}{ E. coli } & \multicolumn{2}{|c|}{$P$. aeruginosa } & \multicolumn{2}{|c|}{ C. albicans } & \multicolumn{2}{|c|}{ A. brasiliensis } \\
\hline & MIC & MMC & MIC & MMC & MIC & MMC & MIC & MMC & MIC & MMC \\
\hline 1600 & - & - & - & - & - & - & - & - & - & - \\
\hline 1440 & - & - & - & - & - & - & - & - & - & - \\
\hline 1280 & - & - & - & - & - & - & - & - & - & - \\
\hline 1120 & - & - & - & - & - & - & - & - & - & - \\
\hline 960 & - & - & - & - & - & - & - & - & - & - \\
\hline 800 & - & - & - & - & + & + & - & - & - & - \\
\hline 640 & - & - & - & - & + & + & + & + & - & - \\
\hline 480 & + & + & + & + & + & + & + & + & - & + \\
\hline 320 & + & + & + & + & + & + & + & + & + & + \\
\hline 160 & + & + & + & + & + & + & + & + & + & + \\
\hline
\end{tabular}

Antimicrobial susceptibility of EO of T. satureioides $\mathrm{C}$. was evaluated by two methods (disc diffusion method and macrodilution). The results showed that all the microbial strains studied were sensitive to EO, except $P$. aeruginosa which exhibited a resilience. Strains of Pseudomonas aeruginosa are known to have multidrug resistance for antibiotics ( Mayaud et al., 2008; Kasrati et al., 2014). It seems that its external membrane and efflux mechanisms protect it against the actions of the EO (Mayaud et al., 2008). These results align with several studies on antimicrobial activity of EO of T. satureioides C. Oussalah et al. (2007) showed that the EO of thymus, was able to inhibit the growth of $S$. aureus and E. coli. El Bouzidi et al. (2013) and Boubaker et al. (2016) reported an inhibitory effect of $E O$ of Moroccan thymus on $C$. albicans and fungi (especially citrus pathogens), respectively. The MIC of $C$. albicans is higher relative to that of $S$. aureus and $E$. coli. This result is in line with previous work which concluded that the $\mathrm{EO}$ of $T$. satureioides $\mathrm{C}$ had moderate anti-fungal activity (Ait-Sidi-Brahim et al., 2018). The comparison of MIC values is complex because of the variability of the methods used (concentrations used, volume of inoculum, culture medium, $\mathrm{pH}$, temperature, incubation time, etc.) (Lawal and Ogunwande, 2013) and the variability of the microbial strains tested. However, it seems that the difference in antimicrobial activity may have been related to the concentration, composition, functional groups, and structural configuration of the compounds and their possible synergistic interactions (Oussalah et al., 2007).

Classically, the antibacterial action of EO relies primarily on lipophilicity, which allows EO to interact with cell membranes and position itself between lipid chains (Sokolik et al., 2018), thus causing a series of 
cellular disturbances, leading to the inhibition of growth, or even bacterial destruction. Some studies suggest that the high thymol content confers this antimicrobial potential to the EO being studied (El Bouzidi et al., 2013), while others have shown that thymol has an antibacterial and antifungal activity (Marchese et al., 2016). Furthermore, other studies highlighted the mechanism of action of Thymol in vitro against Actinobacillus pleuropneumoniae. They reported that thymol disrupts the integrity of the bacterial membrane, leading to the leakage of cell components ultimately causing cell death (Wang et al., 2017). Moreover, other molecules may be implicated in this antimicrobial activity, such as carvacrol and carvone (Zhou et al., 2014; Hakemi-Vala et al., 2017).

\section{Conclusions}

Moroccan thyme can yield $1.01 \%$ of EO. The latter has a borneol chemotype characterised by its richness in phenols and monoterpene alcohols. The extracted EO have significant antimicrobial activity at acceptable levels, particularly against microbial strains responsible for the deterioration of health products.

The $\mathrm{EO}$ of $T$. satureioides $\mathrm{C}$. represent a natural source of antimicrobial substances that exhibited potential for use in pharmaceutical and cosmetic industries, generally, in the field of antimicrobial preservation. The main active components of $\mathrm{EO}$ of $T$. satureioides $\mathrm{C}$. could be used as natural alternatives for protection of health products. However, the use of the $\mathrm{EO}$ of $T$. satureioides $\mathrm{C}$ in its raw form, can pose technical problems due to its insolubility in water, high volatility, aroma, colour and, interference, etc. Hence, encapsulation is one valuable option to solve these issues. Also, molecular screening the EO to identify and extract specific active components that exclusively have the antimicrobial activity would be invaluable.

\section{Authors' Contributions}

KOT: hypothesized and drafted the manuscript. RO: guided drafting of the manuscript. RL: helped in the drafting. SE: Writing - review and editing. All authors read and approved the final manuscript.

\section{Acknowledgements}

This research received no specific grant from any funding agency in the public, commercial, or not-forprofit sectors.

\section{Conflict of Interests}

The authors declare that there are no conflicts of interest related to this article.

\section{References}

Adams RP (2005). Identification of essential oil components by gas review: Identification of essential oil components by gas chromatography/mass spectrometry. Allured Publishing Corporation, Carol Stream IL.

Aicha N, Chendid Rachida T, Meskaoui Abdelmalek E, Ben Abdellah Fez Morocco M (2013). Micropropagation of Thymus satureioides Coss. an endangered medicinal plant of Morocco. Journal of Agriculture and Technology 9:487-501. 
Ainane A, Talbi M, Khammour F, Hamad M, Kouali EL, Abba EH, Cherroud S, Ainane T (2019). Composition chimique et activité anti insecticide des huiles essentielles de Thymus du Maroc: Thymus capitatus, Thymus bleicherianus et Thymus satureioides. Proceedings BIOSUNE 1:96-100.

Ait-Sidi-Brahim M, Markouk M, Larhsini M (2018). Moroccan medicinal plants as anti-infective and antioxidant agents, in: new look to phytomedicine: advancements in herbal products as novel drug leads. Elsevier, pp 91-142. https://doi.org/10.1016/B978-0-12-814619-4.00005-7

Al-Maqtari MAA, Alghalibi SM, Alhamzy EH (2011). Chemical composition and antimicrobial activity of essential oil of thymus vulgaris from Yemen. Turkish Journal of Biochemistry 36:342-349.

Alaoui-Jamali C, Kasrati A, Leach D, Abbad A (2018). Étude comparative de l'activité insecticide des huiles essentielles des espèces de thyms originaires du Sud-Ouest marocain. Phytothérapie 16:268-274. https://doi.org/10.3166/s10298-016-1051-6

Bellakhdar J, Claisse R, Fleurentin J, Younos C (1991). Repertory of standard herbal drugs in the Moroccan pharmacopoea. Journal of Ethnopharmacology 35:123-143. https://doi.org/10.1016/0378-8741(91)90064-K

Boubaker H, Karim H, El Hamdaoui A, Msanda F, Leach D, Bombarda I, ... Ait Ben Aoumar A (2016). Chemical characterization and antifungal activities of four Thymus species essential oils against postharvest fungal pathogens of citrus. Industrial Crops Production 86:95-101. https://doi.org/10.1016/j.indcrop.2016.03.036

Chraibi M, Farah A, Lebrazi S, El Amine O, Iraqui Houssaini M, Fikri-Benbrahim K (2016). Antimycobacterial natural products from Moroccan medicinal plants: Chemical composition, bacteriostatic and bactericidal profile of Thymus satureioides and Mentha pulegium essential oils. Asian Pacific Journal of Tropical Biomedicine 6:836840. https://doi.org/10.1016/j.apjtb.2016.08.002

CLSI (2012). Methods for dilution antimicrobial susceptibility tests for bacteria that grow aerobically; Approved Standard-Ninth Edition. CLSI Doc. M07-A9. Wayne, PA Clin. Lab. Stand. Inst.

El Bouzidi L, Jamali CA, Bekkouche K, Hassani L, Wohlmuth H, Leach D, Abbad A (2013). Chemical composition, antioxidant and antimicrobial activities of essential oils obtained from wild and cultivated Moroccan thymus species. Industrial Crops Production 43:450-456. https://doi.org/10.1016/j.indcrop.2012.07.063

Elkhoudri N, Baali A, Amor H (2016). Maternal morbidity and the use of medicinal herbs in the city of Marrakech, Morocco. Indian Journal Traditional Knowledge 15:79-85.

EUCAST EC on AST (2019). Determination of antibiotic sensitivity. CASFM / EUCAST French Society of Microbiology.

Falleh H, Ben Jemaa M, Saada M, Ksouri R (2020). Essential oils: A promising eco-friendly food preservative. Food Chemistry 330:127268. https://doi.org/10.1016/j.foodchem.2020.127268

Fatima-Zahra E, Fouzia RF, Abdelilah R (2017). Ethnobotanical study of medicinal plants used in traditional medicine in the province of Sidi Kacem, Morocco. Asian Journal of Pharmacy and Clinical Research 10:121-130. https://doi.org/10.22159/ajpcr.2017.v10i1.14326

Hakemi-Vala M, Rafati H, Aliahmadi A, Ardalan A (2017). Nanoemulsions: a novel antimicrobial delivery system. In: Nano- and Microscale Drug Delivery Systems. Elsevier, pp 245-266. https://doi.org/10.1016/B978-0-323-527279.00013-3

Ismaili H, Milella L, Fkih-Tetouani S, Ilidrissi A, Camporese A, Sosa S, Altinier G, Della Loggia R, Aquino R (2004). In vivo topical anti-inflammatory and in vitro antioxidant activities of two extracts of Thymus satureioides leaves. Journal of Ethnopharmacology 91:31-36. https://doi.org/10.1016/j.jep.2003.11.013

Jaafari A, Mouse HA, Rakib EM, M’Barek LA, Tilaoui M, Benbakhta C, Boulli A, Abbad A, Zyad A (2007). Chemical composition and antitumor activity of different wild varieties of Moroccan thyme. Brazilian Journal of Pharmacognosy 17:477-491. https://doi.org/10.1590/S0102-695X2007000400002

Kasrati A, Alaoui Jamali C, Fadli M, Bekkouche K, Hassani L, Wohlmuth H, Leach D, Abbad A (2014). Antioxidative activity and synergistic effect of Thymus saturejoides Coss. essential oils with cefixime against selected food-borne bacteria. Industrial Crops Production 61:338-344. https://doi.org/10.1016/j.indcrop.2014.07.024

Khorshidian N, Yousefi M, Khanniri E, Mortazavian AM (2018). Potential application of essential oils as antimicrobial preservatives in cheese. Innovative Food Science and Emerging Technologies 45:62-72. https://doi.org/10.1016/j.ifset.2017.09.020

Khouya T, Ramchoun M, Hmidani A, El moualij B, Amrani S, Harnafi H, ... Alem C (2019). Acute toxicity and antiproliferative and procoagulant activities of fractions derived from Thymus satureioides of the Moroccan High Atlas. South African Journal of Botany 121:568-576. https://doi.org/10.1016/j.sajb.2019.01.005 
Konaté K, Mavoungou JF, Lepengué AN (2012). Antibacterial activity against $\beta$ - lactamase producing methicillin and ampicillin-resistants Staphylococcus aureus: Fractional Inhibitory Concentration Index (FICI) determination. Annals of Clinical Microbiology and Antimicrobials 11:18.

Lahnine L, Mghazli S, Mahrouz M, Hidar N, Ouhammou M, Mouhib M, Zantar S, ... Misdaq MA (2017). Decontamination by gamma irradiation at low doses of Thymus satureioides and its impact on physico-chemical quality. Food Bioproduction Process 104:48-56. https://doi.org/10.1016/j.fbp.2017.04.006

Laila Z, Fatima G, Rachid M, Abdelaziz B, Chaouki AF (2014). Essential oil composition and biomass productivity of Moroccan endemic Thymus satureioides Coss. Ball. growing in the Agoundis Valley. Journal of Medicinal Plants Research 8:504-512. https://doi.org/10.5897/jmpr2014.5373

Lal M, Baruah J, Begum T, Pandey SK (2020). Identification of a novel myrcene and methyl iso-eugenol rich essential oil variant (Jor Lab L-11) of lemongrass (Cymbopogon flexuosus L.). Journal of Essential Oil-Bearing Plants 23:660668. https://doi.org/10.1080/0972060X.2020.1823893

Lal M, Borah A, Pandey SK (2019). Identification of a new high geraniol rich variety 'Jor Lab L-15' of lemongrass [Cymbopogon khasianus (Hack) Stapf (ex Bor)]. Journal of Essential Oil-Bearing Plants 22:972-978. https://doi.org/10.1080/0972060X.2019.1661797

Lawal OA, Ogunwande IA (2013). Essential oils from the medicinal plants of Africa. Medicinal Plant Research in Africa: Pharmacology and Chemistry 203-224. https://doi.org/10.1016/B978-0-12-405927-6.00005-9

Marchese A, Orhan IE, Daglia M, Barbieri R, Di Lorenzo A, Nabavi SF, ... Nabavi SM (2016). Antibacterial and antifungal activities of thymol: A brief review of the literature. Food Chemistry https://doi.org/10.1016/j.foodchem.2016.04.111

Mayaud L, Carricajo A, Zhiri A, Aubert G (2008). Comparison of bacteriostatic and bactericidal activity of 13 essential oils against strains with varying sensitivity to antibiotics. Letters in Applied Microbiology 47:167-173. https://doi.org/10.1111/j.1472-765X.2008.02406.X

Meyer BK, Ni A, Hu B, Shi L (2007). Antimicrobial preservative use in parenteral products: Past and present. Journal of Pharmacological Science 96:3155-3167. https://doi.org/10.1002/jps.20976

Munda S, Dutta S, Pandey SK, Sarma N, Lal M (2019). Antimicrobial activity of essential oils of medicinal and aromatic plants of the North East India: A biodiversity hot spot. Journal of Essential Oil-Bearing Plants 22:105-119. https://doi.org/10.1080/0972060X.2019.1601032

NCCLS (2002a). Reference Method for Broth Dilution Antifungal Susceptibility Testing of Yeasts. Approv. Stand. Ed. Doc. M27-A2 [ISBN 1-56238-469-4]. NCCLS, 940 West Val. Road, Suite 1400, Wayne, Pennsylvania 190871898 USA.

NCCLS (2002b). NCCLS. Reference Method for Broth Dilution Antifungal Susceptibility Testing of Filamentous Fungi. Approv. Stand. Doc. M38-A [ISBN 1-56238-470-8]. NCCLS, 940 West Val. Road, Suite 1400, Wayne, Pennsylvania 19087-1898 USA.

Oussalah M, Caillet S, Saucier L, Lacroix M (2007). Inhibitory effects of selected plant essential oils on the growth of four pathogenic bacteria: E. coli O157:H7, Salmonella typhimurium, Staphylococcus aureus and Listeria monocytogenes. Food Control 18:414-420. https://doi.org/10.1016/j.foodcont.2005.11.009

Rahman M (2018). Application of computational methods in isolation of plant secondary metabolites. Computational Phytochemistry 107-139. https://doi.org/10.1016/b978-0-12-812364-5.00004-3

Ramchoun M, Harnafi H, Alem C, Büchele B, Simmet T, Rouis M, Atmani F, Amrani S (2012). Hypolipidemic and antioxidant effect of polyphenol-rich extracts from Moroccan thyme varieties. ESPEN Journal 7. https://doi.org/10.1016/j.clnme.2012.02.005

Ramchoun M, Sellam K, Harnafi H, Alem C, Benlyas M, Khallouki F, Amrani S (2015). Investigation of antioxidant and antihemolytic properties of Thymus satureioides collected from Tafilalet Region, south-east of Morocco. Asian Pacific Journal of Tropical Biomedicine 5:93-100. https://doi.org/10.1016/S2221-1691(15)30151-9

Ramzi H, Ismaili MR, Aberchane M, Zaanoun S (2017). Chemical characterization and acaricidal activity of Thymus satureioides C. \& B. and Origanum elongatum E. \& M. (Lamiaceae) essential oils against Varroa destructor Anderson \& Trueman (Acari: Varroidae). Industrial Crops Production 108:201-207. https://doi.org/10.1016/j.indcrop.2017.06.031

Rebbas K, Bounar R (2014). Floristic and ethnobotanical study of medicinal plants of M'Sila (Algeria). Phytotherapie 12:284-291. https://doi.org/10.1007/s10298-014-0872-4

Sakkas H, Papadopoulou C (2017). Antimicrobial activity of basil, oregano, and thyme essential oils. Journal of Microbiology and Biotechnology 27(3):429-438. https://doi.org/10.4014/jmb.1608.08024 
Sokolik CG, Ben-Shabat-Binyamini R, Gedanken A, Lellouche JP (2018). Proteinaceous microspheres as a delivery system for carvacrol and thymol in antibacterial applications. Ultrasonics Sonochemistry 41:288-296. https://doi.org/10.1016/j.ultsonch.2017.09.032

Tahraoui A, El-Hilaly J, Israili ZH, Lyoussi B (2007). Ethnopharmacological survey of plants used in the traditional treatment of hypertension and diabetes in south-eastern Morocco (Errachidia province). Journal of Ethnopharmacology 110:105-117. https://doi.org/10.1016/j.jep.2006.09.011

Taoufik F, Anejjar A, Asdadi A, Salghi R, Chebli B, El Hadek M, Idrissi Hassani LM (2017). Synergic effect between Argania spinosa cosmetic oil and Thymus satureioides essential oil for the protection of the carbon steel against the corrosion in sulfuric acid medium. Journal of Materials and Environmental Science 8:582-593.

Wang L, Zhao X, Zhu C, Xia X, Qin W, Li M, ... Hu J (2017). Thymol kills bacteria, reduces biofilm formation, and protects mice against a fatal infection of Actinobacillus pleuropneumoniae strain L20. Veterinary Microbiology 203:202-210. https://doi.org/10.1016/j.vetmic.2017.02.021

Zhou H, Tao N, Jia L (2014). Antifungal activity of citral, octanal and $\alpha$-terpineol against Geotrichum citri-aurantii. Food Control 37:277-283. https://doi.org/10.1016/j.foodcont.2013.09.057
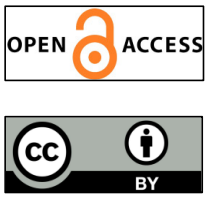

The journal offers free, immediate, and unrestricted access to peer-reviewed research and scholarly work. Users are allowed to read, download, copy, distribute, print, search, or link to the full texts of the articles, or use them for any other lawful purpose, without asking prior permission from the publisher or the author.

License - Articles published in Notulae Scientia Biologicae are Open-Access, distributed under the terms and conditions of the Creative Commons Attribution (CC BY 4.0) License.

(c) Articles by the authors; SHST, Cluj-Napoca, Romania. The journal allows the author(s) to hold the copyright/to retain publishing rights without restriction. 